\title{
Efficiency and Equality of Education: The Effectiveness of Education Policy in the German Federal States'
}

\author{
Raphaela Schlicht-Schmälzle
}

\begin{abstract}
Effizienz und Gleichheit in der Bildung: Die Wirksamkeit der Bildungspolitik in den deutschen Bundesländern

Abstract: The central goal of this paper is to examine the effectiveness of education policy in the German federal states with regard to two central educational outcomes: educational efficiency and equality. Applying a two-stage multi-level analysis, the degrees of efficiency and equality in the German Länder are estimated before the effects of sub-national education policy on these two outcomes are evaluated. A primary finding of the paper is that there is no "efficiency-versus-equality trade-off" in Germany's school education. By contrast, both outcomes are interdependent. Furthermore, education policy has very different impacts on efficiency and equality: Equality of education is mainly determined by early childhood education. Efficiency, however, is affected by the strict tripartite tracking system.
\end{abstract}

Keywords: Education Policy, Efficiency, (In)equality, German Federal States, Two-Stage Multi-Level

Schlagwörter: Bildungspolitik, Effizienz, (Un)gleichheit, Deutsche Bundesländer, Zweistufige Mehrebenenanalyse

\section{Introduction}

The central goal of this paper is to examine the effectiveness of education policy in the German federal states with regard to two central educational outcomes: educational efficiency and social inequality. While efficiency defines the overall societal level of education, inequality describes how educational achievement depends on individuals' social background. Since the publication of the Program for International Student Assessment (PISA), the comparative approach to the effectiveness of education systems has played a pivotal role in Germany's public affairs (Prenzel 2004). The PISA studies uncovered remarkable differences in educational outcomes between national education systems but also between sub-national units such as the German federal states or the Swiss Cantons. Nevertheless, the comparative knowledge on education policy, educational outcomes, and their interaction is still in its fledgling stages. Therefore, this study explicitly

\footnotetext{
1 Many thanks to the PISA-Konsortium and the Forschungsdatenzentrum (FDZ) at the IQB in Berlin for providing the access to the PISA data on the Länder-level.
} 
emphasizes the effects of specific policy programs on educational outcomes (learning achievements). ${ }^{2}$

The following reasons explain the important role of education in today's welfare states (Allmendinger and Leibfried 2003; Busemeyer 2006, 2008; Heidenheimer 1973; Iversen and Stephens 2008; Thelen 2004; Wilensky 1975): First, a society's investment in education is an investment in human capital formation and thus a prerequisite for future economic and technical competitiveness. Moreover, the dependence of educational attainment on social background rather than on individual capabilities is seen as a waste of human capital (Handl 1985). Second, the school education system can be regarded as the foundation of a meritocratic society since it determines overall societal mobility (Müller and Pollak 2004). According to Esping-Andersen (1990), education policy as social policy is a tool to regulate societal stratification. Third, from the perspective of modernization theory, education is also relevant for the functioning of democracies and for the political culture (Coleman 1966; Hadjar and Becker 2006; Lipset 1959).

Recently, several cross-national and sub-national comparative studies have focused on the impact of education policy on the degrees of social inequality of education: Cross-national comparative studies have examined how national education policy moderates the relationship between individuals' social backgrounds and educational achievement (inequality) (Ammermüller 2005; Pfeffer 2008; Schütz et al. 2008; Schlicht et al. 2010). The main results of these studies are that early childhood education, all-day school, education expenditures, tracking in secondary education, and the private school sector moderate the degree of educational inequality. However, a weakness of these studies is the neglect of decentralization of education in several countries and the sub-national composition of education policy and educational inequality. Therefore, more recent studies pay special attention to sub-national comparisons of the German federal states and the Swiss Cantons (Freitag and Schlicht 2009; Schlicht 2010a, 2010b; Stadelmann-Steffen 2011; Woessmann 2010). The main results are that the onset of institutional tracking, early childhood education and the availability of the all-day school are responsible for the degrees of inequality in access to Gymnasium.

In spite of this effort, several questions still remain unsettled: The described studies all focus on educational inequality as the central measure of educational effectiveness. However, Kolberg and Esping-Andersen (1992) first introduced the concept of the efficiency-versus-equality-trade-off in the welfare state. Accordingly, weaker inequality structures in the economic system are often accompanied by stronger inefficiency. Following Pontusson $(2005$, p. 2$)$ " $[t]$ he theme of equality and efficiency, whether and how they might be reconciled, lies at the core of democratic politics in capitalist societies, always lurking behind the narrower issues that we contest in elections and legislative battles." In Germany for instance,

2 The study first and foremost narrows the analytical window to the link between policy output and outcome. It neither focuses on the very important aspects of policy-process efficiency nor on the link between policy actors and policy outputs. Especially Pierson (2006) suggests that political science should focus stronger on the link between policy outputs as institutions and their effects on individuals' lives. 
recent ambitions to implement studying-fees in higher education are seen by some people as necessary for improving university education (efficiency) while others expect increasing degrees of social inequality in higher education. ${ }^{3}$ With regard to school education, the debate on the school reform referendum in Hamburg 2010 - especially on the postponement of tracking from $5^{\text {th }}$ to $7^{\text {th }}$ grade - raised the questions of efficiency and equality. ${ }^{4}$ However, apart from Woessmann (2010), none of the referred studies focused on educational efficiency. Woessmann (2010) started to explore the impact of education policy on inequality and efficiency of education in the German federal states. The present study expands this effort by using different outcome measures and by including a broader set of explanatory variables. In this study, I focus on the reliability of the effects by testing them on diverse education outcomes (reading, mathematics, and science). Furthermore, previous studies (e.g. Freitag and Schlicht 2009; Woessmann 2010) established early childhood education as an integral factor of educational inequality. To explore this effect in more detail, a differentiation is made between different types of early childhood education in Germany (Kinderkrippe, Kindergarten, and preschool). Finally, the study furthermore widens the analytic perspective by accounting for a comprehensive set of non-policy control variables (socio-economic, socio-cultural, and political conditions).

This article is organized as follows: in the next section, the concepts of educational efficiency and equality will be established and compared between the Länder. The third section provides a theoretical approach and the hypotheses on the education policy implications. In a fourth section, the two-stage multi-level analysis and the data on the macro-political conditions will be presented. Following the presentation of the results in section five, the paper will conclude with a discussion of the major findings and an outlook for future research.

\section{Educational Efficiency and Equality}

How can the degrees of school educational efficiency and equality be conceptualized? According to Woessmann (2010) and the PISA studies (Prenzel et al. 2005), efficiency of education is defined as the overall educational achievement in society. From this perspective, the overall capabilities (in mathematics, reading, and science) are an important macro-societal indicator for the general level of educational achievement in the Bundesländer. Students' learning achievements in specific school subjects can be regarded as key outcomes of the education system. Furthermore, especially sciences and mathematics are largely independent of cultural backgrounds and therefore allow a less normative comparison of educational outcomes across geographical regions such as nation states and sub-national units. Unquestionable, there are various further indicators of effectiveness and efficiency of the education system: Important examples include capacities such as

3 http://www.faz.net (06-03-2008: "SPD, Grüne und Linke schaffen Studiengebühren in Hessen $a b ")$.

4 http://www.zeit.de (07-18-2010: “Schwarz-Grün verliert den Schul-Volksentscheid”); http://www. faz.net (07-19- 2010: "CDU kritisiert Hamburger CDU”). 
social competence, the adaptability of skills to labour market requirements, or the achievement of soft skills that facilitate independent participation in higher education. However, it seems impossible to address all these capacities at once in this study. Furthermore, the meanings of these outcomes are highly dependent on cultural backgrounds and thus hardly comparable between geographical regions. Equality of school education is, by contrast, defined as the equal distribution of educational achievement among different social classes. In the following, inequality of education is therefore conceptualized as the dependence of educational achievement (capabilities in mathematics, reading, and science) on individuals' social background (Boudon 1973; Bourdieu 1983).

The measures of individual educational performance (capabilities) as well as the measure of individual social background have been gathered from the PISA-E 2003 (Prenzel et al. 2005). The study provides reliable data on these variables for the $9^{\text {th }}$ graders in 2003 representative for all 16 German federal states. Social background is measured by the highest International Socio-Economic Index of Occupational Status (ISEI) of both parents (Ganzeboom et al. 1992). The capability of pupils in three school subjects (mathematics, science, and reading) is measured by several tests in PISA-E 2003. ${ }^{5}$ This dataset provides highly up-to-date and accessible data on the sub-national level. ${ }^{6}$ In order to generate the indicators of educational efficiency in each federal state (j), the mean of individual pupils' (i) achievement scores $(\mathrm{y})$ in a specific subject is calculated across all observed pupils (n) in model A:

Model A: Mean $_{Y j}=1 / n_{j} \sum_{j=1}^{n_{j}} y_{i j}$

For describing the degree of social inequality of school education, the achievement $(\mathrm{Y})$ of a person (i) with a certain social background $(\mathrm{x})$ in mathematics, readings, and science in a federal sate $(\mathrm{j})$ controlled by the variables $(\mathrm{k})$ is estimated by linear regressions for each federal state (Model B). The effect of social background on educational success is controlled by gender and migration status (cp. e.g. Lamb 1989: 166; Levels et al. 2008; Roscigno and Ainsworth-Darnell 1999). The generated linear regression coefficients $\left(\beta_{\mathrm{xj}}\right)$ represent the extent of social inequality of school education in 16 German federal states.

Model B: $\mathrm{Y}_{\mathrm{ij}}=\alpha_{\mathrm{j}}+\beta_{\mathrm{xj}} \mathrm{x}_{\mathrm{ij}}+\beta_{\mathrm{kj}} \mathrm{k}_{\mathrm{ij}}+\varepsilon$

Figure 1 displays the mean science achievement of pupils in the German federal states (compare Model A). Accordingly, Saxony and Bavaria provide the most efficient school systems among the German federal states regarding science educa-

5 Following Levels et al. (2008) the mean of five "Plausible Values" is used to measure the availability in each subject.

6 Very recently, the sub-national level data of PISA 2006 have been published (and should be analyzed soon). Nevertheless, cross-national country rankings of PISA 2000 - PISA 2009 evince extremely high correlations, suggesting that the development of educational outcomes over time represents a rather stable phenomenon. 
tion. Moreover, the credibility intervals show that the Länder differ significantly with regard to educational efficiency. When focusing on pupils' mean capabilities in readings and mathematics, the ranking in Figure 1 is strongly confirmed. We can thus indeed identify generally efficient and general inefficient sub-national school systems.

Figure 1: Mean science achievement and 95\% confidence intervals

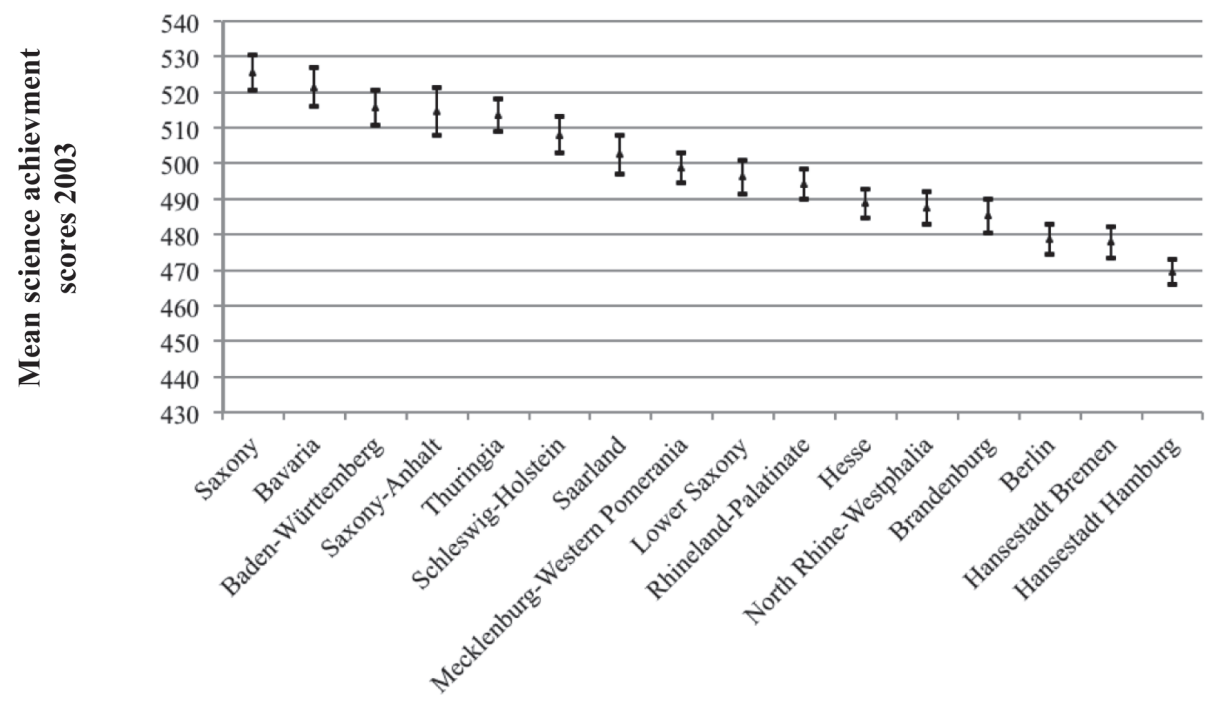

Figure 2 presents the effects of individuals' social backgrounds on their achievement scores in the German federal states ( $\beta_{\mathrm{xj}}$ in model B). The degrees of inequality indeed vary between the Länder. Nevertheless, the variation is surprisingly low, since only a few countries show significant differences. The degree of social inequality of school education is highest in Hamburg. These measures of inequality are highly correlated with the inequality of mathematic and reading achievements, confirming reliable rankings of educational inequality. 
Figure 2: Social inequality in science achievement and $95 \%$ confidence intervals
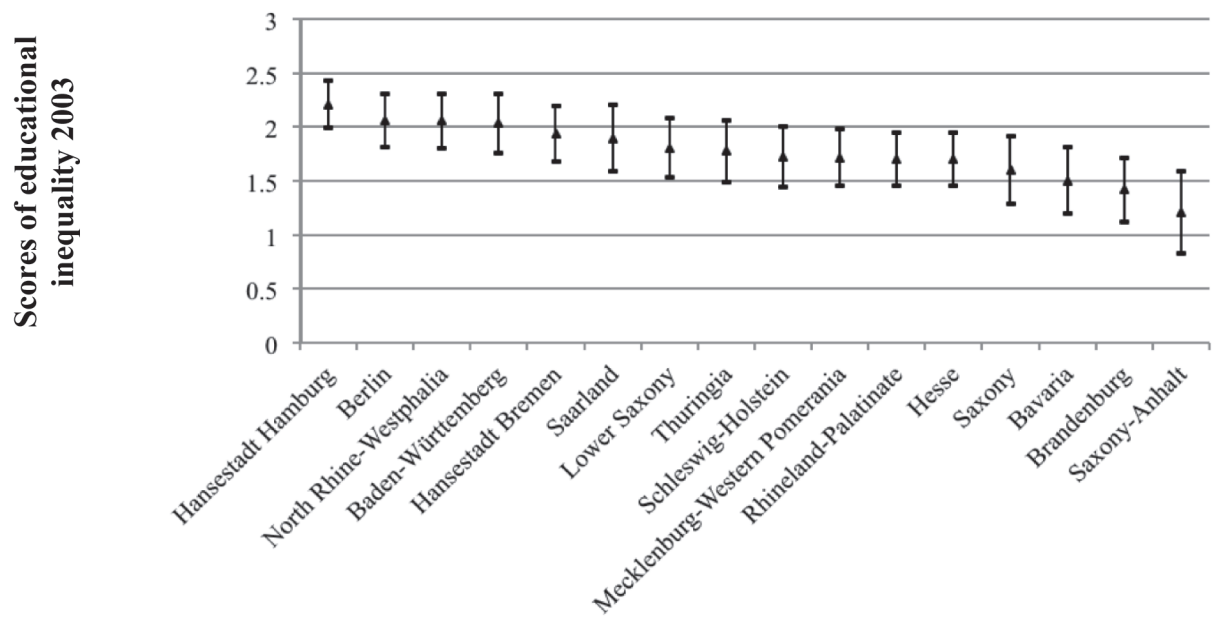

Furthermore, it has to be clarified how the degree of social inequality of education is related to efficiency of education (cp. Kolberg and Esping-Andersen 1992, p. 10). Is there an "equality-efficiency trade-off" in Germany's education welfare system? The measures of efficiency and measures of inequality are all negatively correlated $(\mathrm{r} \leq-0.4)$ (also cp. Woessmann 2010, p. 248). Thus, the higher the educational efficiency, the lower is its degree of inequality. Equality and efficiency in Germany's education welfare state are therefore not conflicting but even interdependent. Thus "inequality of opportunity can indeed be seen as a source of inefficiency as it implies a misallocation of natural talent" (cp. Pontusson 2005, p. 4). 
Figure 3: Negative relationship between science competences and social inequality of science competences 7

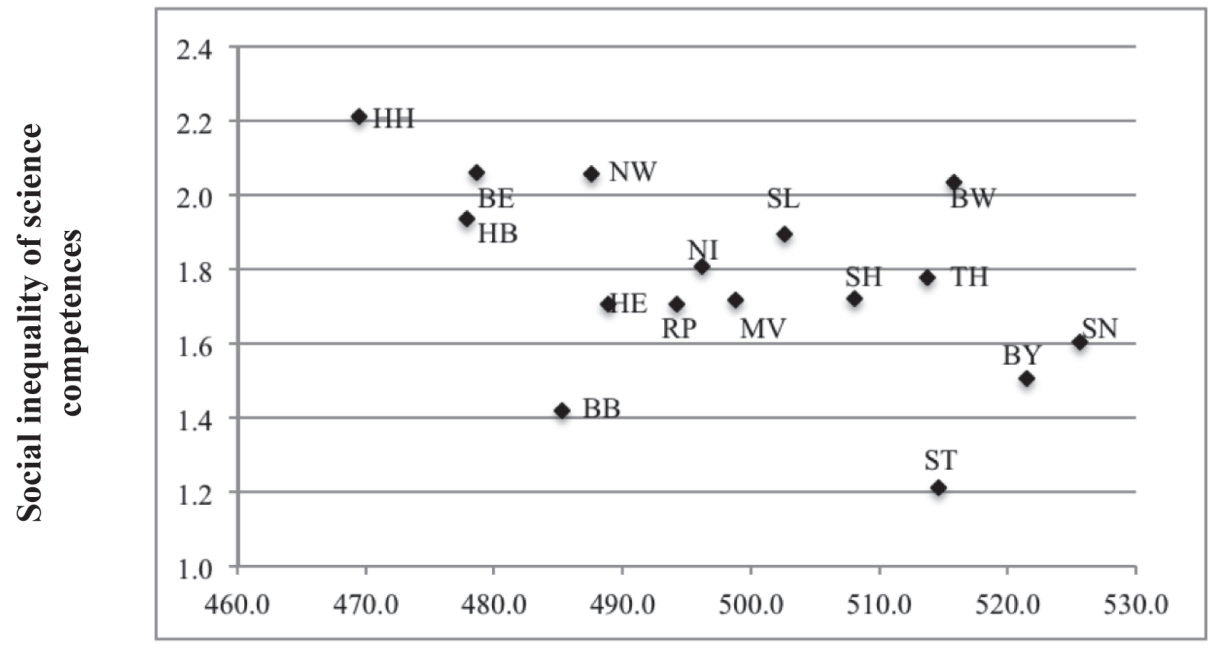

\section{The Impact of Education Policy on Educational Efficiency and Equality}

Following the core tenets of the new institutionalism, institutional rules, procedures and conventions mould individual preferences, thereby encouraging or limiting options by means of certain incentive mechanisms (Hall and Taylor 1996; Ostrom 1999). From the new institutional perspective, macro-political institutions - such as education policy - serve as incentives for individual educational behaviour and opportunities. Pierson (2006) has called for a stronger consideration of public policies as institutions because they constitute the framework that affects people in their everyday lives. The goal of the present work is to contribute to this demand by evaluating sub-national education policy with regard to its effects on key educational outcomes. The key thesis is that education policy structures pupils' education opportunities and therefore acts as a filter for individual educational success (cp. figure 3). The following hypotheses focus on education policies of the German states (Länder) that are highly discussed in political debates. In this study, the focus is on how the Länder-level and its distinct education policy framework affects education outcomes.

7 Abbreviations of federal states names: Baden-Wuerttemberg (BW), Bavaria (BY), Berlin (BE), Brandenburg (BB), Hansestadt Bremen (HB), Hansestadt Hamburg (HH), Hesse (HE), Lower Saxony (NI), North-Rhine Westphalia (NW), Mecklenburg-Western Pomerania (MV), RhinelandPalatinate (RP), Saarland (SL), Saxony (SN), Saxony-Anhalt (ST), Schleswig-Holstein (SH), Thuringia (TH). 
Figure 3: Macro-political explanation of educational outcomes

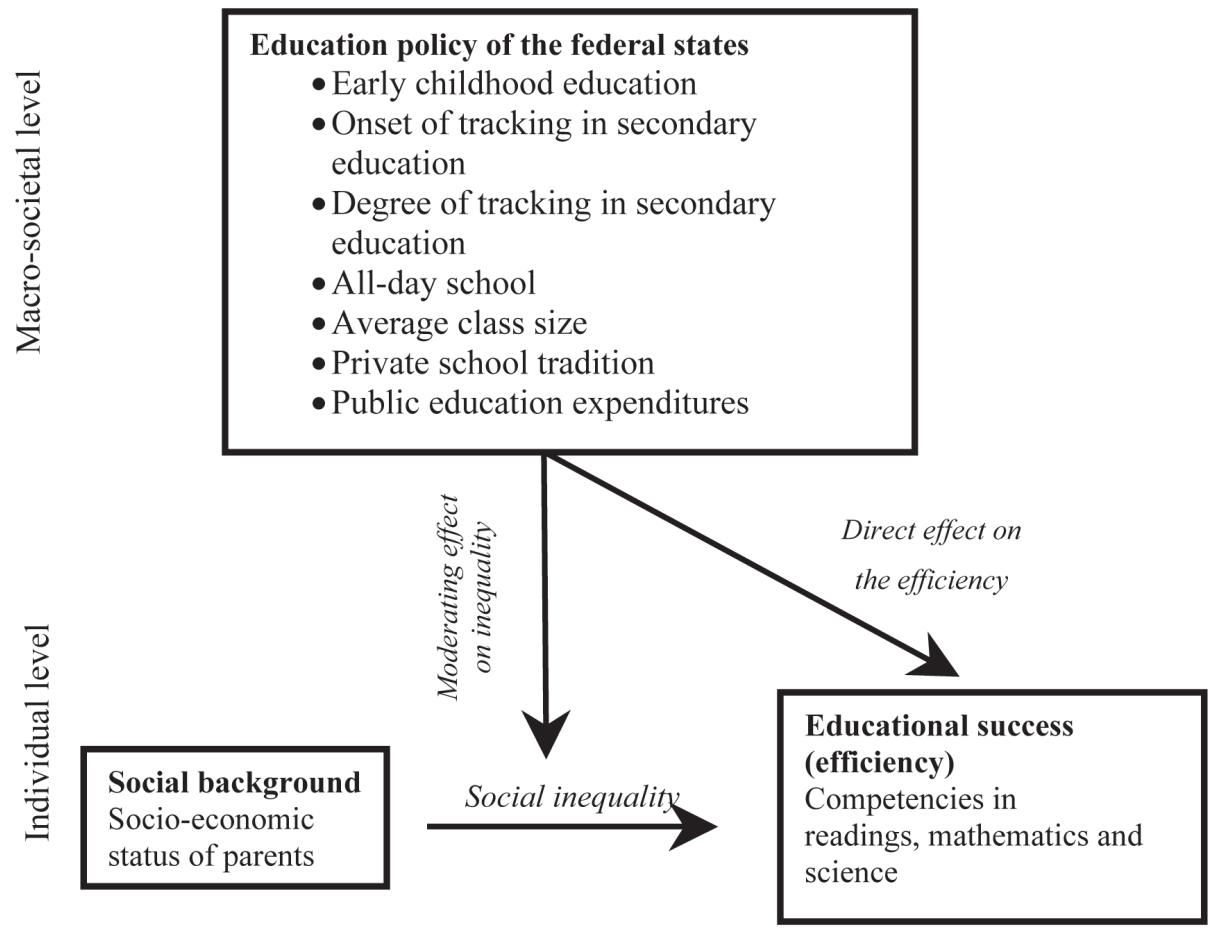

Preschool education: It is widely assumed that early childhood education is able to act as a surrogate for insufficient capital resources at home (Magnuson et al. 2006). Consequently, class-specific disparities in educational requirements could be levelled off prior to starting primary school (McClelland and Acock 2006). While children from lower social strata can profit from an enriching early childhood environment, those exclusively socialised by their parents have reduced chances of internalising enriching external influences. By fostering the achievement of the lower social classes, a strong early childhood education system should moreover increase the general level of educational achievement in society (efficiency).

$H 1 a_{(\text {efficiency): }}$ : An encompassing early childhood education enrolment in the German federal states should increase the efficiency of education.

$H 1 b_{(\text {equality) }}$ : An encompassing early childhood education enrolment in the German federal states should reduce the degree of social inequality of education.

All-day school: The German school system is traditionally a half-day school system even though the prevalence of all-day school has recently expanded. In the half-day school tradition, organisation of leisure time depends entirely on families. For example, the availability of remedial teaching or participation in educa- 
tional leisure activities is very much dependent on parents' resources. Children coming from less well-off families are at a definite disadvantage compared to their more privileged counterparts. In all-day schools, pupils, regardless of their social background, are socialised in a similar and enriching environment over the period of a full day (Becker and Lauterbach 2004). By improving the achievement of children from lower social classes, the all-day school system should moreover lead to a general increase of educational achievement in society (efficiency).

$H 2 a_{(e f f i c i e n c y}:$ The higher all-day school enrolment in the German federal states, the stronger is the efficiency of education.

$H 2 b_{\text {(equality) }}$ : The higher all-day school enrolment in the German federal states, the lower is the degree of social inequality of education.

Average class size: The average class size is often seen as an indicator for the quality of teaching and learning processes in a country (Szelewa and Polakowski 2008, p. 118). A small class size indicates that one teacher is responsible for a small number of pupils, enabling the teacher to provide more attention to individual pupils (Graddy and Stevens 2005). According to Mosteller (1995), pupils from lower social classes primarily suffer from the lack of individual encouragement in large classes. Parents of pupils from more privileged backgrounds may compensate for the shortcomings of educational quality at school by providing additional support. The encouraging effect of small class sizes on the achievement of children from lower social classes should moreover lead to a general increase of educational achievement in society (efficiency).

$H 3 a_{\text {(efficiency): }}$ The smaller the average class size in the German federal states, the higher is the efficiency of education.

$H 3 b_{(e q u a l i t y)}$ : The smaller the average class size in the German federal states, the lower is the degree social inequality of education.

School education expenditures: Low expenditures generally result in decreased educational investments and will possibly be substituted by a high proportion of private education expenditures (cp. Schmidt 2002). This shift of responsibility from the state to the private sector may ultimately lead to different prospects for educational achievements among social classes (cp. Roscigno and Ainsworth-Darnell 1999). Beyond that, public education expenditures emphasise the societal importance of education (Schmidt 2002). This symbolic policy message may be transmitted to society and incorporated into individual education behaviours (cp. Jones and Cullis 2003). Since education expenditures strengthen the value of education in all social classes, increasing expenditures should moreover increase achievement of education in general (efficiency).

$H 4 a_{\text {(efficiency): }}$ The higher the public school education expenditures in the German federal states, the higher is the efficiency of education.

$H 4 b_{(\text {equality) }}$ : The higher the public school education expenditures in the German federal states, the lower is the degree social inequality of education. 
Tracking in secondary education: Another main characteristic of education policy is whether or not institutional tracking of pupils during secondary education into hierarchically ordered educational programmes, each with varying academic reputations, takes place. The intention of tracking is to "create instruction groups that are homogeneous with respect to student abilities" (Hallinan 1996, p. 983). However, in practice, a strict selection of pupils into hierarchically ordered and separated school types increases social inequality in education (Gamoran and Mare 1989; Jonsson 1990). According to rational choice theories, educational decisions regarding school types depend mainly on parents' educational assumptions and tastes, and not only on children's educational goals or abilities (Becker 2000; Goldthorpe 1996). Tracking will thus be associated with more socially biased educational decisions (Lucas 2001, p. 1646). However, the risk of a reduced tracking system is that it hinders education that corresponds to pupils' individual capabilities. Thus, reducing tracking can in turn reduce the achievement of highly gifted pupils and thus reduce the general societal educational achievement (efficiency).

One main characteristic of the German education system is the traditional early institutional tracking of pupils. Uncertainty about one's own educational capabilities is especially high at the beginning of educational careers (Hillmert 2005). Educational decisions for special school types will thus depend mainly on parents' educational assumptions, and less on the children's educational goals or abilities. Lucas (2001, p. 1646) argues: "if students are less dependent on their parents for later transitions, then social background should be less important for determining who receives additional schooling."

$H 5 a_{(e f f i c i e n c y)}$ : The more pupils are tracked later than after the $4^{\text {th }}$ grade in the German federal states, the lower is the efficiency of education.

$H 5 b_{\text {(equality): }}$ The more pupils are tracked later than after the $4^{\text {th }}$ grade in the German federal states, the lower is the degree of educational inequality.

In addition to the timing of the tracking, the degree of tripartition in secondary school education should also be significant for social inequality. A strict selection of pupils into three hierarchically ordered and separated school types (Gymnasium, Realschule, and Hauptschule) is supposed to lead to a high degree of social inequality in education, since penetrability among school types is thereby avoided (Jonsson 1990). As indicators for the weak degree of selectivity, a diminished autonomy of the Hauptschule and the presence of comprehensive schools should reduce the degree of social disparity. Investigations of the Hauptschule's student body reveal a significant and long-standing segregation of children from less advantaged social backgrounds and ethnic minorities that restricts transition to further school types (Solga and Wagner 2001). Comprehensive schools circumvent socially selective school decisions by parents or teachers since they provide a common curriculum to all pupils, independent of their academic abilities in the same school. Co-operative comprehensive schools use in-school tracking: several graduation types are available within the same institution. Integrative compre- 
hensive schools are more far-reaching in dissolving tracking since pupils are taught altogether in the same classroom.

H6a (efficiency): The less independent the Hauptschule is in the German federal states, the lower is the educational efficiency.

$H 6 b_{(e q u a l i t y)}$ : The less independent the Hauptschule is in the German federal states, the lower is the degree of educational inequality.

$H 7 a_{(e f f i c i e n c)}:$ The higher comprehensive school enrolment in the German federal states, the lower is the efficiency of education.

$H 7 b_{(\text {equality) }}$ : The higher comprehensive school enrolment in the German federal states, the lower is the degree of educational inequality.

Private school: Private schools are assumed to perform better than public schools as they may provide more individualised attention and encouragement (Coleman et al. 1982). The market-oriented principal-agent relation within private schools shifts power to the pupils and their parents as the agents. Furthermore, private schools are presumed to have greater financial resources for providing individual support. Private schools also tend to exhibit an advantageous social environment or even constitute "functional communities", providing a favourable school climate for better school performance (Chubb and Moe 1988; Coleman et al. 1982). On the other hand, the net effect of private schools on social inequality of education tends to be positive due to the social selection processes. Most importantly, private schools mainly attract pupils from high income and better-educated families (Wrinkle et al. 1999). However, a strong private school sector should still lead to an increase of the general educational achievement in society (efficiency) since it is supposed to have no effect, neither a positive nor a negative one, on the achievement of the lower social classes but solely a positive effect on pupils' from better well-off families.

$H 8 a_{(e f f i c i e n c y}$ : The stronger the private school sector in the German federal states, the higher the efficiency of education.

$H 8 b_{(e q u a l i t y)}$ : The stronger the private school sector in the German federal states, the stronger the degree social inequality of education.

Obviously, there are various further micro- and meso-level policies that affect the teaching and learning process. Especially, factors as teacher-student interactions or the accountability of parents and teachers are relevant factors that vary from classroom to classroom, from school to school, and from school-county to school-county. However, not only these very deep characters of the education process, which are very close to the individual student, will affect pupils' learning outcomes. This paper therefore focuses on the more general framework and resources of the education system on the Länder-level. These macro-political factors are expected as important for the learning and teaching quality on the microlevel. 


\section{Methods and Data}

\subsection{A Two-stage hierarchical approach}

The effect of single educational policy factors on educational efficiency and equality is analysed via a two-stage multi-level analysis (cp. Franzese 2004). The data structure of the fundamental research question is nested: How does the sub-national context (macro-level) affect pupils' individual school achievement (individual level) and how does it moderate the relation between individual social background (individual level) and individual school success (individual level)? Two-stage hierarchical estimations are more efficient than "pooled-sample" models when the number of units of analysis on the individual level (26,628 pupils in PISA-E 2003) exceeds the number of observations on the contextual level (16 federal states) by a multiple and when the research question centres the macrosocietal aspects (sub-national education policy) (Franzese 2004, p. 431, 443). In the first analytical stage, the approach analyses parameters to describe the efficiency and inequality of education (cp. section 2). In the second stage, the estimated parameters of the first analytical stage become the dependent variables: The revealed means of school achievement and the effects of individual social background on school educational success $\left(\beta_{\mathrm{xj}}\right)$ will be explained by macro political factors (federal state specific education policy $P_{j}$ ):

Efficiency $_{j} /$ Inequality ${ }_{j}=\alpha+\beta_{p} P_{j}+\varepsilon$ (cp. Duch and Stevenson 2004, p. 394).

To reveal reliable effects of education policy on the degrees of efficiency and inequality of education, the models are analysed for all indicators of educational efficiency and inequality (see models 1-6). The education policy effects are controlled for relevant socio-economic, socio-cultural and political variables (K).

Model (1): Efficiency of the reading achievement ${ }_{j}=\alpha+\beta_{\mathrm{p}} \mathrm{P}_{\mathrm{j}}+\beta_{\mathrm{k}} \mathrm{K}_{\mathrm{j}}+\varepsilon$ Model (2): Efficiency of the mathematics achievement $t_{j}=\alpha+\beta_{p} P_{j}+\beta_{k} K_{j}+\varepsilon$ Model (3): Efficiency of the science achievement ${ }_{j}=\alpha+\beta_{\mathrm{p}} \mathrm{P}_{\mathrm{j}}+\beta_{\mathrm{k}} \mathrm{K}_{\mathrm{j}}+\varepsilon$

Model (4): Inequality of the reading achievement $t_{j}=\alpha+\beta_{\mathrm{p}} \mathrm{P}_{\mathrm{j}}+\beta_{\mathrm{k}} \mathrm{K}_{\mathrm{j}}+\varepsilon$ Model (5): Inequality of the mathematics achievement ${ }_{j}=\alpha+\beta_{p} P_{j}+\beta_{k} K_{j}+\varepsilon$ Model (6): Inequality of the science achievement ${ }_{j}=\alpha+\beta_{p} P_{j}+\beta_{k} K_{j}+\varepsilon$

Given that the dependent variables are not observable but estimated parameters of the first analytical stage, common Ordinary Least Square estimates are inappropriate (Hanushek 1974, p. 66).$^{8}$ Therefore, the following analyses on the second stages use FGLS-estimates, thereby weighting the dependent variables in the second stages by their precision (Hanushek 1974; Lewis and Linzer 2005).

8 The regression residuals of the second stage possess two components: the sample error and the stochastic error. 
The small number of 16 cases (Länder) requires parsimonious models (cp. Achen 2002). Each model therefore only includes one education policy factor (P) not controlling for the other education policy variables (final models cp. appendices 2-8)..$^{9}$ Each education policy factor is controlled by further non-education policy factors. According to Achen (2002, p. 446), each model includes 3 variables ( 2 control variables plus 1 education policy variable) to achieve parsimony. A non-education policy factor is evaluated as relevant for a model if it shows a bivariate significant effect on the particular outcome (efficiency or inequality of education). ${ }^{10}$ As the number of observations (16 Länder) is fairly small when compared to the three explanatory variables, a statistical $\alpha$-error is unlikely. Statistical $\beta$-errors are more likely, since $\beta$-coefficients become less likely statistically significant. Education policy effects are evaluated as stable when they are significant $(\mathrm{p}<0.05)$ in at least one model of educational efficiency or educational inequality and the coefficients in all models show the same direction. Moreover, robustness for each model is tested by Bayesian statistics, heteroskedasticity consistent covariance matrices (hc3 method) (Long and Ervin 2000) and Jackknife- and Bootstrap estimations. ${ }^{11}$

\subsection{Measuring education policy and the control variables}

The data for education policy institutions were gathered from databases of the German Federal Statistical Office and the Conference of the Education Ministers (appendices $1 \mathrm{a}$ and $1 \mathrm{~b}$ ). Importantly, the data were collected for the time points in the past that were relevant for the observed population of $9^{\text {th }}$ graders in 2003. This means for the education policy indicators that we observe a rather historical situation in the past (especially for early childhood education) to respect the longterm effects of education policies on students' outcomes. More precisely, today's accessibility of early childhood education will not affect today's $9^{\text {th }}$ graders' education outcomes. The present education policy situation in the federal states and especially the changes after PISA can therefore not yet be evaluated realistically. We therefore have to respect history to understand today's outcomes. Based on that knowledge we can draw a conclusion for current policy reforms. The availability of early childhood education is measured by the availability of the three types of early childhood education in Germany: the Krippe, the Kindergarten,

9 This is mainly reasoned by partly strong correlations between the education policy variables and the risk of multicollinearity.

10 A relevant non-education effect is only included to the model if it is not correlated with the policy factor $(r>0.5)$. Furthermore, the included control variables must not be related with each other $(r>0.5)$. In case of a strong correlation, the factor with the higher explanatory power $\left(\mathrm{r}^{2}\right)$ is included.

11 Robustness checks: Bayesian statistics are highly suitable for non-random samples. In this study, a parameter is regarded as reliably negative or positive if it has a probability of $80 \%$ to be below or above 0 . As a prior I used a mean of 0 and a standard deviation of 10000 to keep its impact low. Results are moreover checked by heteroskedasticity consistent covariance matrices (parameters reported in the result tables in the appendix) (cp. Long and Ervin 2000, p. 223). These models provide standard errors that are robust against heteroskedasticity. Applying Bootstrap and Jackknife techniques, effects are controlled for influential outliers (Rodgers 1999). 
and the preschools. The availability of the Krippe is measured by the ratio of children enrolled in a Krippe to the total number of children between ages 0 and 2 . The availability of the Kindergarten is measured by the ratio of children enrolled in a Kindergarten to the total number of children ages 3-5. ${ }^{12}$ The enrolment in preschool education is measured by the enrolment rates of all six-year-old children in preschool institutions. The availability of the all-day school is measured by the percentage of pupils in all-day schools. The average class size is measured by the mean teacher-to-pupil ratio on all school levels. The school education expenditures are measured by the mean expenditures in Euro per year and pupil. The onset of tracking is measured by the percentage of pupils that are not tracked after 4th grade of primary school but attend a transition school in grades 5 and 6 or a 6-year long primary school. Traditionally, pupils in Germany are tracked after the $4^{\text {th }}$ grade. Some further federal states have introduced the possibility to postpone tracking to the end of grade 6 . The existence and independence of the Hauptschule is gathered from the sub-national school laws. States that provide a completely independent Hauptschule are coded by 0 . In states that provide a Hauptschule exclusively affiliated to another secondary school type (mostly the Realschule) or that abolished the Hauptschule completely are coded by 1 . The availability of co-operative and integrative comprehensive schools is measured by the percentage of pupils enrolled in these school types. The relevance of the private school sector is measured by the mean percentage of all pupils that are enrolled in private schools on all school levels.

Beyond the education policy variables, several socio-economic, socio-cultural, and political control variables are considered. The east-west divide of the federal states is measured by a dummy variable. Berlin is coded as a western federal state, since the western German school law has been applied to the whole city-state after reunification. The economic wealth of the federal states is measured by the Gross Domestic Product (GDP) per capita (1994-2002). The traditional party dominance in the federal states is measured by the percentage of left-wing parties (SPD, Bündnis 90/Die Grünen, and Die Linke) and respectively right-wing parties (CDU and FDP) in all state governments from 1949 on. ${ }^{13}$ The Catholic and Protestant tradition in the federal states is measured by the percentage of Catholics or respectively Protestants of all citizens (2005). Urbanization is measured by the number of citizens per squared kilometre (2003). The degree of migration is measured by the percentage of foreigners in the federal states (1994-2002). ${ }^{14}$

12 Vaules $>100 \%$ mean an enrolment of children beyond the age cohort of 3-5.

13 Or from the year of foundation on.

14 Freitag and Vatter (2008) show that the German federal states differ decisively regarding their politico-institutional frameworks. However, there is no argument how political institutions, such as the electoral system, should directly affect educational outcomes. Political institutions may act rather indirectly, via specific party political constellations within the federal states that shape education policies. However, in this case it would be impossible to control the policy effects on the outcomes for institutional effects since the former (policy) would not be independent but rather a result of the latter (polity) (cp. Schlicht 2010b, p. 189-190). 


\section{Results}

Does the composition of education policy in the federal states affect efficiency and equality of education? Table 1 summarizes the effects of education policy institutions on these two educational outcomes.

Table 1: The effects of education policy on equality and efficiency of education

\begin{tabular}{lcc}
\hline Education Policy & Educational Efficiency & Educational Inequality \\
\hline Availability of the "Krippe" & - & diminishing \\
\hline Availability of the "Kindergarten" & - & diminishing \\
\hline Enrolment in the preschool & diminishing & enforcing \\
\hline Availability of the all-day school & - & - \\
\hline Average class size & - & - \\
\hline School education expenditures & - & - \\
\hline Late tracking & diminishing & - \\
\hline Abolishment of the "Hauptschule" & - & - \\
\hline Co-operative comprehensive schools & enforcing & - \\
\hline Integrative comprehensive Schools & diminishing & - \\
\hline Private school sector & - & - \\
\hline
\end{tabular}

Hypothesis $1 a$ is clearly rejected for all three types of early childhood education. The availability of early childhood education in the German federal states is not related to the general degree of educational achievement in society (efficiency). By contrast, hypothesis $1 b$ is strongly confirmed since the availability of the Kinderkrippe and the Kindergarten is indeed associated with a reduced degree of educational inequality. In line with Woessmann (2010), early childhood seems to equalize the abilities between the social classes. Furthermore, the effect of preschool education on both educational outcomes cannot be completely clarified. The results indeed contradict hypotheses $1 a$ and $1 b$. Inequality of education seems to be even enforced by preschool education while efficiency is even diminished. However, the effect of preschool education on both outcomes cannot be definitely separated from the further macro societal effects. ${ }^{15}$

Hypotheses $2 a, 2 b, 3 a, 3 b, 4 a$, and $4 b$ are completely rejected. The availability of the all-day school, average class sizes, and education expenditures are neither related to efficiency nor to the degree of educational inequality in the German federal states.

15 The effect of preschool education on the efficiency of education cannot be controlled for migration and GDP, since these factors are both highly positively correlated with enrolment in preschool education. The enforcing effect of preschool education on the degree of inequality of education cannot be separated from the urbanisation effect on inequality of education since both factors are again positively correlated. 
The tracking hypothesis $5 a$ is confirmed since later tracking indeed is negatively related to efficiency of school education in the German federal states. This supports the fear that more heterogeneous instruction groups in $5^{\text {th }}$ and $6^{\text {th }}$ grade reduce the overall educational achievement of pupils. Hypothesis $5 b$, however, is rejected, since the onset of tracking is in contrast to Woessmann (2010), not related to the degree of education inequality in the federal states. The conflicting findings may result from different measures of the onset of tracking: Woesmann's dummy indicator remains on a rather abstract level describing the regulative rules on the Länder level but not the actual implementation of delayed tracking.

Hypotheses $6 a$ and $6 b$ are both rejected. A non-existing Hauptschule or a Hauptschule that only exists in affiliation to higher ranked school types does neither contribute to an equalization of the capabilities among social classes nor does it increase the overall educational achievement of pupils.

Hypothesis $7 a$ is confirmed for integrative comprehensive schools but contradicted for co-operative comprehensive schools. On the one hand, the more heterogeneous instruction groups in integrated comprehensive schools are associated with a lower general achievement of capabilities in the federal states, what supports hypothesis $7 \mathrm{a}$. On the other hand, the co-operative comprehensive schools are positively associated to efficiency of education, what contradicts hypothesis $7 a .{ }^{16}$ Hypothesis $7 b$, however, cannot be confirmed for both types of comprehensive schools. Pupils' capabilities are not levelled out by the introduction of comprehensive schools.

Hypothesis $8 a$ and $8 b$ both cannot be confirmed. The private school sector neither affects the efficiency nor the equality of education. Woessman (2010) found a profound negative effect of the private school sector on inequality. In the present study, this effect did not remain stable when controlling for catholic denomination.

What about the socio-cultural, socio-economic, and political control variables? Do further non-educational context conditions affect the efficiency and the inequality of education in the federal states? Beyond the onset of tracking and the introduction of comprehensive schools, the party political tradition in the federal states also shows consistent effects on the measures of educational efficiency. The stronger the traditional dominance of right-wing parties (CDU and FDP), the stronger is the efficiency of education. This effect is stable over all models when controlling it for further contextual variables and policy effects. When the education policy effects are controlled by the party politics effect, none of the policy effects remains stable. However, education policies are all strongly correlated with party dominance in the federal states. Therefore, I expect that party politics do not directly affect the efficiency of education but indirectly affect it via education policies. In this case, it is wrong to control for the indirect party politics ef-

16 This effect cannot be controlled for the relevant socio-cultural context conditions - migration and GDP per capita - since they are correlated with the availability of the co-operative comprehensive school. However, since these effects have not been significant in models controlled by policy effects as the onset of tracking and the integrative comprehensive school, the policy effect of the co-operative comprehensive school is also assumed to be stable against migration and GDP per capita. 
fect (cp. Schlicht 2010b). The GDP per capita and the percentage of migration also showed bivariate effects on efficiency of education. However, these effects did not remain significant when controlling for further education policy conditions. Social inequality of school education is, in addition to education policies, affected by the degree of urbanization in the federal states. The stronger the urbanization, the higher is the degree of social inequality of education.

The previous analyses confirmed the central thesis that education policy, even when controlled for socio-economic, socio-cultural, and political conditions, is related to educational efficiency and inequality. For educational efficiency, diverse policy factors were identified as being relevant. This raises the question as to which of these policies - late tracking, cooperative comprehensive schools, and integrative comprehensive schools - are most important. By calculating several models including different combinations of the policies, it is shown that not all of these policies remain significant. It is remarkable that the negative effect of the integrative comprehensive school on educational efficiency remains steadily significant. When combining the late tracking variable with one of the comprehensive school variables in a model, the comprehensive school variables remain significant. Taken together, these results might indicate that the comprehensive school variables are more relevant for efficiency than late tracking and that the negative effect of the integrative comprehensive school is more important than the positive effect of the cooperative comprehensive school.

\section{Conclusion}

The goal of this paper was to evaluate sub-national education policy with regard to two central educational outcomes: efficiency and equality of education. A primary finding of the study is that the degrees of both school educational efficiency and inequality indeed differ between the German federal states. Moreover, the analyses cannot identify an efficiency-versus-equality-trade-off in Germany's education system. A high level of educational achievement is not in conflict with low degrees of educational inequality in the German Länder.

At a second analytical stage, the major findings confirm that efficiency and equality of education are indeed associated with education policy in the federal states. Educational efficiency is mainly related to matters of the tracking system in secondary education: A late onset of tracking (later than after the $4^{\text {th }}$ grade) and the introduction of integrative comprehensive schools reduce the efficiency of education, while the availability of the co-operative comprehensive schools improves efficiency. Comparing the effects of the three tracking variables, the comprehensive school seems to be more important than the onset of tracking. In contrast, educational inequality is only related to the availability of early childhood education. The better the availability of the Kinderkrippe and the Kindergarten, the lower is the degree of inequality of school education. In line with Esping-Andersen (1990), especially early childhood education can be seen as a social policy tool to regulate stratification in Germany's education system. Thus, a regulative reduction of educational inequalities between social classes should be established in early curricular stages. It remains unclear why early childhood education redu- 
ces educational inequality but does not affect the mean achievement rates (efficiency) in the Länder. One explanation may be that only children from very low social classes benefit from early childhood education whereas wealthier children remain rather unaffected. All the other school education policies cannot be confirmed to mould inequality structures in the federal states. This however, may indicate that a provision of all-day schools and low pupils-to-teachers ratios alone do not guarantee lower degrees of inequality. By contrast, it has to be considered which additional learning activities all-day schools provide and which social classes benefit from all-day schools and low pupils-to-teacher ratios. Especially, the lack of an effect of educational expenditures shows that strong financial resources do not automatically lead to high quality education systems. It is thus valuable to not only observe the quantity of policy activities but also the quality of their implementation. The results marginally conflict with the findings of Woessmann (2010). This may result from different measures of the policy variables. Furthermore, the present study focuses on various outcome measures (mathematics, readings, and science) to improve the reliability of the policy effects.

The results emphasize that educational efficiency and equality are affected by different education policy aspects. At a first glance, there are no conflicting policy implications for efficiency and equality. Thus, efficiency and equality of education can be achieved simultaneously but by different policy programs. Nevertheless, the result of the onset of tracking is remarkable with regard to a potential efficiency-versus-equality-trade-off in education. According to the results of this study, a late onset of tracking reduces the overall achievement of education in the federal states (efficiency). By contrast, it does not affect the dependence of the achievement of capabilities on individuals' social background ([in]equality). This provides support for the abolishment of late tracking in Lower Saxony 2004 and Bremen 2005, and also for the referendum against the introduction of later tracking in Hamburg 2010. Nevertheless, earlier studies indeed identified a diminishing effect of late tracking on inequality in access to Gymnasium (Freitag and Schlicht 2009; Schlicht 2010a, 2010b). This trade-off reflects peoples' concerns during the referendum in Hamburg 2010: On the one hand, supporters of the reform aimed at reducing inequality of school education access by late tracking. On the other hand, the electorate abolished the reform due to the risk of hindering education that corresponds to pupils' individual abilities.

Beyond education policy, the political and socio-cultural context also seems to affect the degrees of efficiency and social inequality of education. The traditional dominance of right-wing parties, (CDU and FDP), in the federal states from 1949 on enforces the efficiency of school education. However, the analyses support the assumption that the causal impact of party politics works not directly on educational outcomes but indirectly over education policy. Therefore, it can be concluded that right wing-parties implement policies such as early tracking and the cooperative comprehensive school that encourage efficiency. They also reject the introduction of integrative comprehensive schools that lowers efficiency of education. However, the literature on party political preferences in concrete education policy output (except education expenditures) is still underdeveloped and should be considered in future research. On the other hand, party politics do not affect 
the degree of educational inequality. Educational inequality is mainly affected by the urbanization of the federal states, since the achievement of capabilities is actually more unequal in urbanized regions.

In future research, the analysis of the efficiency-versus-equality trade-off from a cross-national comparative level would enrich current knowledge on the relation between these highly relevant outcomes and their macro-societal determinants (cp. Horn 2009). The effects of education policies on educational inequality are much stronger on the cross-national comparative level (cp. Schlicht et al. 2010). Furthermore, it would be valuable to evaluate the educational reforms after PISA and their long-term effects on students' educational achievements. In this regard, it will be an important question whether PISA leads to a convergence of the subnational education and whether this affected the heterogeneity of educational outcomes among the Länder.

\section{References}

Achen, Christopher H. 2002. Toward a New Political Methodology: Microfoundations and ART. Annual Review of Political Science 5:423-450.

Allmendinger, Jutta, and Stephan Leibfried. 2003. Education and the Welfare State: the Four Worlds of Competence Production. Journal of European Social Policy 13:63-81.

Ammermüller, Andreas. 2005. Educational Opportunities and the Role of Institutions. http://edocs.ub.unimaas.nl/loader/file.asp?id=1071. Accessed: 30.7.2009.

Becker, Rolf. 2000. Klassenlage und Bildungsentscheidungen. Kölner Zeitschrift für Soziologie und Sozialpsychologie 52:450-475.

Becker, Rolf, and Wolfgang Lauterbach. 2004. Die immerwährende Frage der Bildungsungleichheit im neuen Gewand. In Bildung als Privileg? Erklärungen und Befunde zu den Ursachen von Bildungsungleichheit, Eds. Rolf Becker and Wolfgang Lauterbach, 429445. Wiesbaden: VS Verlag für Sozialwissenschaften.

Boudon, Raymond. 1973. Education, opportunity, and social inequality. New York: Wiley. Bourdieu, Pierre. 1983. Ökonomisches Kapital, kulturelles Kapital, soziales Kapital. In Soziale Ungleichheiten, Ed. Reinhard Kreckel, 183-198. Göttingen: Verlag Otto Schwartz $\&$ Co.

Busemeyer, Marius R. 2006. Die Bildungsausgaben der USA im internationalen Vergleich. Politische Geschichte, Debatten und Erklärungsansätze. Wiesbaden: DUV Verlag.

Busemeyer, Marius R. 2008. Education and the "New" Social Democracy: an Analysis from the View of Comparative State Expenditure Research. Politische Vierteljahresschrift 49: 283-308.

Chubb, John E., and Terry M. Moe. 1988. Politics, Markets, and the Organization of Schools. The American Political Science Review 82:1066-1087.

Coleman, James S. 1966. Equality of Educational Opportunity. Washington: U.S. Government Printing Office.

Coleman, James S., Thomas Hoffer, and Sally Kilgore. 1982. Cognitive Outcomes in Public and Private Schools. Sociology of Education 55:65-76.

Duch, Raymond M., and Randy Stevenson. 2004. Context and the Economic Vote: A Multilevel Analysis. Political Analysis 13:387-409. 
Esping-Andersen, Gøsta. 1990. The Three Worlds of Welfare Capitalism. Cambridge: Polity Press.

Franzese, Robert J. 2004. Empirical Strategies for Various Manifestations of Multilevel Data. Political Analysis 13:430-446.

Freitag, Markus, and Adrian Vatter (Eds.). 2008. Die Demokratien der deutschen Bundesländer. Politische Institutionen im Vergleich. Opladen: Barbara Budrich (UTB).

Freitag, Markus, and Raphaela Schlicht. 2009. Educational Federalism in Germany. Foundations of Social Inequality of Education. Governance 22:47-72.

Gamoran, Adam, and Robert D. Mare. 1989. Secondary School Tracking and Educational Inequality: Compensation, Reinforcement, or Neutrality? American Journal of Sociology 94:1146-1183.

Ganzeboom, Harry B. G., Paul M. De Graaf, and Donald J. Treiman. 1992. A Standard International Socio-Economic Index of Occupational Status. Social Science Research 21:1-56.

Goldthorpe, John H. 1996. Class Analysis and the Reorientation of Class Theory. The Case of Persisting Differentials in Educational Attainment. British Journal of Sociology 47:481-501.

Graddy, Kathryn, and Margaret Stevens. 2005. The Impact of School Resources on Student Performance. A Study of Private Schools in the United Kingdom. Industrial \& Labor Relations Review 58:435-451.

Hadjar, Andreas, and Rolf Becker. 2006. Educational Expansion and the Change of Political Interest in West Germany, 1980-2002. Politische Vierteljahresschrift 47:12-34.

Hall, Peter A., and Rosemary C. R. Taylor. 1996. Political Science and the Three New Institutionalisms. Political Studies 44:936-957.

Hallinan, Maureen T. 1996. Track Mobility in Secondary School. Social Forces 74:9831002.

Handl, Johann. 1985. Mehr Chancengleichheit im Bildungssystem. Kölner Zeitschrift für Soziologie und Sozialpsychologie 37:698-722.

Hanushek, Eric A. 1974. Efficient Estimators for Regressing Regression Coefficients. American Statistician 28:66-67.

Heidenheimer, Arnold J. 1973. The Politics of Public Education, Health and Welfare in the USA and Western Europe: How Growth and Reform Potentials have Differed. British Journal of Political Science 3:315-340.

Hillmert, Steffen. 2005. Bildungsentscheidungen und Unsicherheit. Soziologische Aspekte eines vielschichtigen Zusammenhangs. Zeitschrift für Erziehungswissenschaft 8:173186.

Horn, Daniel. 2009. Age of Selection Counts. A Cross-Country Analysis of Educational Institutions. Educational Research and Evaluation 15:343-366.

Iversen, Torben, and John D. Stephens. 2008. Partisan Politics, the Welfare State, and Three Worlds of Human Capital Formation. Comparative Political Studies 41:600-637.

Jones, Philip, and John Cullis. 2003. Key Parameters in Policy Design: The Case of Intrinsic Motivation. Journal of Social Policy 32:527-547.

Jonsson, Jan. 1990. Educational Reform and Changes in Inequality in Sweden. In The Comprehensive School Experiment Revisited: Evidence from Western Europe, Eds. Achim Leschinsky and Karl-Ulrich Mayer, 139-173. Frankfurt a. M.: Peter Lang. 
Kolberg, Jon E., and Gøsta Esping-Andersen. 1992. Welfare States and Employment Regimes. New York: M. E. Sharpe.

Lamb, Stephen. 1989. Cultural Consumption and the Educational Plans of Australian Secondary School Students. Sociology of Education 62:95-108.

Levels, Mark, Jaap Dronkers, and Gerbert Kraaykamp. 2008. Immigrant Children's Educational Achievement in Western Democracies: Origin, Destination, and Community Effects on Mathemetical Performance. American Sociological Review 73:835-853.

Lewis, Jeffrey B., and Drew A. Linzer. 2005. Estimating Regression Models in which the Dependent Variable is Based on Estimates. Political Analysis 13:345-364.

Lipset, Seymour M. 1959. Some Social Requisites of Democracy - Economic Development and Political Legitimacy. American Political Science Review 53:69-105.

Long, J. Scott, and Laurie H. Ervin. 2000. Using Heteroscedasticity Consistent Standard Errors in the Linear Regression Model. American Statistician 54:217-224.

Lucas, Samuel R. 2001. Effectively Maintained Inequality: Education Transitions, Track Mobility, and Social Background Effects. American Journal of Sociology 106:16421690.

Magnuson, Katherine A., Christopher Ruhm, and Jane Waldfogel. 2006. The Persistence of Preschool Effects. Do Subsequent Classroom Experiences Matter? Early Childhood Research Quarterly 22:18-38.

McClelland, Megan M., and Alan C. Acock. 2006. The Impact of Kindergarten LearningRelated Skills on Academic Trajectories at the End of Elementary School. Early Childhood Research Quarterly 21:471-490.

Mosteller, Frederick. 1995. The Tennessee Study of Class Size in the Early School Grades. Future of Children 5:113-127.

Müller, Walter, and Reinhard Pollak. 2004. Social Mobility in West Germany. The Long Arms of History Discovered? In Social Mobility in Europe, Ed. Richard Breen, 77-113. Oxford: Oxford University Press.

Ostrom, Elinor. 1999. Institutional Rational Choice: An Assessment of the Institutional Analysis and Development Framework. In Theories of the Policy Process, Ed. Paul A. Sabatier, 35-71. Boulder: Westview Press.

Pfeffer, Fabian T. 2008. Persistent Inequality in Educational Attainment and its Institutional Context. European Sociological Review 25:1-23.

Pierson, Paul. 2006. Public Policies as Institutions. In Rethinking Political Institutions. The Art of the state, Eds. Ian Shapiro, Stephen Skowronek, and Daniel Galvin, 114-131. New York: New York University Press.

Pontusson, Jonas. 2005. Inequality and Prosperity. Social Europe versus Liberal America. New York: Cornell University Press.

Prenzel, Manfred. 2004. PISA 2003. Der Bildungsstand der Jugendlichen in Deutschland - Ergebnisse des zweiten internationalen Vergleichs. Münster: Waxmann.

Prenzel, Manfred, Jürgen Baumert, Werner Blum, Rainer Lehmann, Detlev Leutner, Michael Neubrand, Reinhard Pekrun, Jürgen Rost, and Ulrich Schiefele. 2005. PISA 2003. Der zweite Vergleich der Länder in Deutschland - Was wissen und können Jugendliche? Münster: Waxmann.

Rodgers, Joseph L. 1999. The Bootstrap, the Jackknife, and the Randomization Test: A Sampling Taxonomy. Multivariate Behavioral Research 34:441-456. 
Roscigno, Vincent J., and James W. Ainsworth-Darnell. 1999. Race, Cultural Capital, and Educational Resource. Persistent Inequalities and Achievement Returns. Sociology of Education 72:158-178.

Schlicht, Raphaela. 2010a. Bildungspolitische Determinanten sozialer Bildungsungleichheit im Bundesländervergleich. In Vergleichende subnationale Analysen für Deutschland, Eds. Markus Freitag and Adrian Vatter, 233-267. Berlin: LIT Verlag.

Schlicht, Raphaela. 2010b. Determinanten der Bildungsungleichheit. Die Leistungsfähigkeit von Bildungssystemen im Vergleich der deutschen Bundesländer. Wiesbaden: VS Verlag für Sozialwissenschaften.

Schlicht, Raphaela, Isabelle Stadelmann-Steffen, and Markus Freitag. 2010. Educational Inequality in the EU. The Effectiveness of the National Education Policy. European Union Politics 11:29-59.

Schmidt, Manfred G. 2002. Warum Mittelmaß? Deutschlands Bildungsausgaben im internationalen Vergleich. Politische Vierteljahresschrift 43:3-19.

Schütz, Gabriela, Heinrich W. Ursprung, and Ludger Wößmann. 2008. Education Policy and Equality of Opportunity. Kyklos 61:279-308.

Solga, Heike, and Sandra Wagner. 2001. Paradoxie der Bildungsexpansion. Die doppelte Benachteiligung von Hauptschülern. Zeitschrift für Erziehungswissenschaft 4:107-129.

Stadelmann-Steffen, Isabelle. 2011. Education Policy and Educational Inequality - Evidence from the Swiss Laboratory. Forthcoming in European Sociological Review. doi: 10.1093/esr/jcq071.

Szelewa, Dorata, and Michael P. Polakowski. 2008. Who Cares? Changing Patterns of Childcare in Central and Eastern Europe. Journal of European Social Policy 18:115131.

Thelen, Kathleen. 2004. How Institutions Evolve. The Political Economy of Skills in Germany, Britain, the United States, and Japan. Cambridge: Cambridge University Press.

Wilensky, Harold L. 1975. The Welfare State and Equality. Structural and Ideological Roots of Public Expenditures. Berkeley/Los Angeles: University of California Press.

Woessmann, Ludger. 2010. Institutional Determinants of School Efficiency and Equity: German States as a Microcosm for OECD Countries. Jahrbücher für Nationalökonomie und Statistik 230:234-270.

Wrinkle, Robert D., Joseph Stewart, and Jerry Polinard. 1999. Public School Quality, Private Schools, and Race. American Journal of Political Science 43:1248-1253.

\section{Author information:}

Dr. Raphaela Schlicht-Schmälzle,

University of Konstanz, Department of Politics and Public Administration,

Universitätsstraße 10

78464 Konstanz,

raphaela.schlicht-schmaelzle@uni-konstanz.de 


\section{Appendix 1a: Descriptive statistics}

\begin{tabular}{lrrrrrc}
\hline $\begin{array}{l}\text { Federal } \\
\text { state }\end{array}$ & Krippe & $\begin{array}{c}\text { Kinder- } \\
\text { garten }\end{array}$ & Pre-school & $\begin{array}{c}\text { All-day } \\
\text { school }\end{array}$ & $\begin{array}{c}\text { Class } \\
\text { size }\end{array}$ & $\begin{array}{c}\text { Expen- } \\
\text { ditures }\end{array}$ \\
Years & 198617 & $\begin{array}{r}1990- \\
199218\end{array}$ & 1993 & 200219 & $\begin{array}{c}1993- \\
2003\end{array}$ & $\begin{array}{c}1980- \\
200320\end{array}$ \\
\hline Saarland & $0.38 \%$ & $95.00 \%$ & $5.23 \%$ & $4.30 \%$ & 16.2 & 4109.51 \\
Rhineland-Palatinate & $0.38 \%$ & $97.67 \%$ & $4.23 \%$ & $5.70 \%$ & 15.4 & 4028.22 \\
North-Rhine Westphalia & $0.37 \%$ & $74.61 \%$ & $8.20 \%$ & $14.60 \%$ & 15.4 & 4044.93 \\
Lower Saxony & $0.90 \%$ & $66.37 \%$ & $19.37 \%$ & $6.20 \%$ & 14.7 & 4281.62 \\
Hansestadt Bremen & $0.89 \%$ & $74.70 \%$ & $20.78 \%$ & $4.60 \%$ & 12.8 & 5150.42 \\
Schleswig-Holstein & $0.56 \%$ & $63.83 \%$ & $28.73 \%$ & $3.60 \%$ & 14.8 & 4186.30 \\
Hansestadt Hamburg & $10.95 \%$ & $52.43 \%$ & $47.91 \%$ & $5.70 \%$ & 13 & 5744.96 \\
Mecklenburg-Western & $49.96 \%$ & $105.24 \%$ & $2.52 \%$ & $8.10 \%$ & 15.2 & 4550.75 \\
Pomerania & $64.56 \%$ & $124.39 \%$ & $0.00 \%$ & $10.70 \%$ & 14.1 & 4068.64 \\
Brandenburg & $44.95 \%$ & $117.18 \%$ & $32.15 \%$ & $21.90 \%$ & 13.3 & 4878.89 \\
Berlin & $32.81 \%$ & $115.73 \%$ & $1.81 \%$ & $22.30 \%$ & 14.4 & 4910.58 \\
Saxony & $0.88 \%$ & $72.28 \%$ & $0.00 \%$ & $2.30 \%$ & 15.8 & 4304.44 \\
Bavaria & $1.18 \%$ & $104.03 \%$ & $7.78 \%$ & $5.80 \%$ & 14.5 & 4297.20 \\
Baden-Württemberg & $1.46 \%$ & $90.43 \%$ & $12.14 \%$ & $13.70 \%$ & 15.6 & 4123.15 \\
Hesse & $54.04 \%$ & $125.10 \%$ & $2.14 \%$ & $21.40 \%$ & 12.8 & 5312.84 \\
Thuringia & $43.37 \%$ & $98.09 \%$ & $4.38 \%$ & $9.60 \%$ & 13.4 & 4989.06 \\
\hline Saxony-Anhalt & & & & & &
\end{tabular}

17 Data for 1987-1989 are not available. Values for1986 serve as an approximation; 1991 for the eastern states; mean of 1986-1991 for Berlin.

18 For the eastern federal states: values of 1991 and 1992. For Berlin: mean of 1990 and 1991.

19 The availability of the all-day school is relevant for the whole period of schooling from 1993 to 2003. However the all-day school statistic of the Conference of the education ministers begins in 2002 what can serve as an approximation.

20 1992-2003 in the eastern states 


\section{Appendix 1b: Descriptive statistics}

\begin{tabular}{lrrrrr}
\hline $\begin{array}{l}\text { Federal } \\
\text { state }\end{array}$ & $\begin{array}{c}\text { Onset of } \\
\text { tracking }\end{array}$ & $\begin{array}{c}\text { Haupt- } \\
\text { schule }\end{array}$ & $\begin{array}{r}\text { Integrative } \\
\text { compre- } \\
\text { hensive } \\
\text { school }\end{array}$ & $\begin{array}{c}\text { Cooperative } \\
\text { comprehen- } \\
\text { sive school }\end{array}$ & $\begin{array}{r}\text { Private } \\
\text { school } \\
\text { sector }\end{array}$ \\
Years & 1998 & 1998 & $1998-2002$ & $1998-2002$ & $1994-$ \\
\hline Saarland & $0.00 \%$ & 1 & $16.00 \%$ & $38.2 \%$ & $7.00 \%$ \\
Rhineland-Palatinate & $0.00 \%$ & 0 & $4.60 \%$ & $10.4 \%$ & $6.10 \%$ \\
North-Rhine Westphalia & $0.00 \%$ & 0 & $15.60 \%$ & $0.0 \%$ & $6.40 \%$ \\
Lower Saxony & $89.80 \%$ & 0 & $4.10 \%$ & $0.4 \%$ & $4.50 \%$ \\
Hansestadt Bremen & $96.20 \%$ & 0 & $13.00 \%$ & $0.0 \%$ & $7.70 \%$ \\
Schleswig-Holstein & $0.00 \%$ & 0 & $6.60 \%$ & $0.0 \%$ & $3.70 \%$ \\
Hansestadt Hamburg & $1.40 \%$ & 1 & $27.70 \%$ & $3.5 \%$ & $8.30 \%$ \\
Mecklenburg-Western & $0.00 \%$ & 0 & $4.80 \%$ & $9.3 \%$ & $1.40 \%$ \\
Pomerania & $82.60 \%$ & 1 & $40.10 \%$ & $0.0 \%$ & $1.30 \%$ \\
Brandenburg & $92.10 \%$ & 0 & $20.60 \%$ & $0.0 \%$ & $4.00 \%$ \\
Berlin & $0.00 \%$ & 1 & $0.00 \%$ & $53.0 \%$ & $1.50 \%$ \\
Saxony & $0.30 \%$ & 0 & $0.30 \%$ & $0.0 \%$ & $8.60 \%$ \\
Bavaria & $0.20 \%$ & 0 & $0.50 \%$ & $0.0 \%$ & $6.30 \%$ \\
Baden-Württemberg & $35.10 \%$ & 1 & $17.30 \%$ & $0.0 \%$ & $4.90 \%$ \\
Hesse & $0.00 \%$ & 1 & $1.20 \%$ & $62.8 \%$ & $2.10 \%$ \\
Thuringia & $90.20 \%$ & 1 & $0.80 \%$ & $22.8 \%$ & $1.50 \%$ \\
Saxony-Anhalt & & & & &
\end{tabular}

Appendix $\mathbf{2}^{22}$ : The effect of the Kinderkrippe enrolment on educational inequality

\begin{tabular}{lccc}
\hline & $\begin{array}{c}\text { Inequality } \\
\text { reading achievement }\end{array}$ & $\begin{array}{c}\text { Inequality } \\
\text { mathematic } \\
\text { achievement }\end{array}$ & $\begin{array}{c}\text { Inequality } \\
\text { science achievement }\end{array}$ \\
\hline Krippe & $-0.01^{*}$ & $-.00(1)($ n.s. $)$ & $-0.00(4)^{* * *}$ \\
\hline Urbanization & $0.00(01)^{*}$ & $0.00(01)^{* *}$ & $0.00(02)^{* *}$ \\
East-West divide & n.i. $^{23}$ & n.i. & n.i. \\
GDP & n.i. & n.i. & n.i. \\
Protestant tradition & n.i. & n.i. & n.i. \\
Migration & n.i. & n.i. & n.i. \\
adj. $\mathbf{R}^{2}$ & 0.2894 & 0.2390 & 0.4875 \\
\hline & & &
\end{tabular}

21 Values of 1991: not available in the eastern federal states. Values of 1993, 1994: not available for all federal states.

22 Remark for the appendices 2-8: ${ }^{*} \mathrm{p}<0.1 ; * \mathrm{*}<0.05 ; * * \mathrm{p}<0.001$. Effects are regarded as stable when they are significant for at least one of the three outcome measures and when they show the same direction in all three models.

23 n.i.= Not included in the model 
Appendix 3: The effect of the Kindergarten enrolment on educational inequality

\begin{tabular}{lccc}
\hline & $\begin{array}{c}\text { Inequality } \\
\text { reading } \\
\text { achievement }\end{array}$ & $\begin{array}{c}\text { Inequality } \\
\text { mathematic } \\
\text { achievement }\end{array}$ & $\begin{array}{c}\text { Inequality } \\
\text { science achievement }\end{array}$ \\
\hline Kindergarten & $-0.01 * *$ & $-.00(2)$, (n.s.) & $-.0000(3)$, (n.s.) \\
\hline Urbanization & $0.00(01)^{*}$ & $0.00(01)^{* *}$ & positiv, n.s. \\
East-West divide & n.i. & n.i. & n.i. \\
GDP & n.i. & n.i. & $0.00(002)$, n.s. \\
Protestant tradition & n.i. & n.i. & n.i. \\
Migration & n.i. & n.i. & n.i. \\
adj. R. $^{2}$ & 0.3360 & 0.2941 & 0.4104 \\
\hline
\end{tabular}

Appendix 4: Effect of the preschool enrolment on educational efficiency

\begin{tabular}{lccc}
\hline & $\begin{array}{c}\text { Level } \\
\text { reading achievement }\end{array}$ & $\begin{array}{c}\text { Level } \\
\text { mathematic } \\
\text { achievement }\end{array}$ & $\begin{array}{c}\text { Level } \\
\text { science achievement }\end{array}$ \\
\hline Preschool & $-0.51^{*}$ & $-0.71^{* *}$ & $-0.73 * *$ \\
\hline CDU dominance & n.i. & n.i. & n.i. \\
GDP per capita & n.i. & n.i. & n.i. \\
Migration & n.i. & n.i. & n.i. \\
adj. $\mathbf{R}^{2}$ & 0.1833 & 0.2851 & 0.3189 \\
\hline
\end{tabular}

Appendix 5: The effect of the preschool enrolment on educational inequality

\begin{tabular}{lccc}
\hline & $\begin{array}{c}\text { Inequality } \\
\text { reading achievement }\end{array}$ & $\begin{array}{c}\text { Inequality } \\
\text { mathematic } \\
\text { achievement }\end{array}$ & $\begin{array}{c}\text { Inequality } \\
\text { science achievement }\end{array}$ \\
\hline Preschool & $0.01 * *$ & $0.01 * *$ & $0.01 * *$ \\
Urbanization & n.i. & n.i. & n.i. \\
East-West divide & n.i. & n.i. & n.i. \\
GDP & n.i. & n.i. & n.i. \\
Protestant tradition & $.00(4)$, n.s. & n.i. & n.i. \\
Migration & n.i. & n.i. & $0.02 * *$ \\
adj. R. $^{2}$ & 0.3912 & 0.2385 & 0.6062 \\
\hline
\end{tabular}


Appendix 6: Effect of the late onset of tracking on educational efficiency

\begin{tabular}{lccc}
\hline & $\begin{array}{c}\text { Level } \\
\text { reading } \\
\text { achievement }\end{array}$ & $\begin{array}{c}\text { Level } \\
\text { mathematic } \\
\text { achievement }\end{array}$ & $\begin{array}{c}\text { Level } \\
\text { science achievement }\end{array}$ \\
\hline Onset of tracking & $-0.18 * *$ & $-0.21 * *$ & $-0.17 *$ \\
\hline CDU dominance & n.i. & n.i. & n.i. \\
GDP per capita & n.i. & $-0.00(1)$, (n.s.) & $-0.00(1)$, (n.s.) \\
Migration & n.i. & -1.16, (n.s.) & -0.92, (n.s.) \\
adj. $\mathrm{R}^{2}$ & 0.2305 & 0.4625 & 0.3715 \\
\hline
\end{tabular}

Appendix 7: Effect of the co-operative comprehensive school on educational efficiency

\begin{tabular}{lccc}
\hline & $\begin{array}{c}\text { Level } \\
\text { reading achievement }\end{array}$ & $\begin{array}{c}\text { Level } \\
\text { mathematic } \\
\text { achievement }\end{array}$ & $\begin{array}{c}\text { Level } \\
\text { science achievement }\end{array}$ \\
$\begin{array}{l}\text { Co-operative } \\
\text { comprehensive school }\end{array}$ & $0.27 * 24$ & $0.40 * *$ & $0.42 * *$ \\
\hline CDU dominance & n.i. & n.i. & n.i. \\
GDP per capita & n.i. & n.i. & n.i. \\
Migration & n.i. & n.i. & n.i. \\
adj. $\mathbf{R}^{2}$ & 0.1707 & 0.1981 & 0.2310 \\
\hline
\end{tabular}

Appendix 8: Effect of the integrative comprehensive school on educational efficiency

\begin{tabular}{lccc}
\hline & $\begin{array}{c}\text { Level } \\
\text { reading achievement }\end{array}$ & $\begin{array}{c}\text { Level } \\
\text { mathematic } \\
\text { achievement }\end{array}$ & $\begin{array}{c}\text { Level } \\
\text { science achievement }\end{array}$ \\
$\begin{array}{l}\text { Integrative } \\
\text { comprehensive school }\end{array}$ & $-0.90^{* *}$ & $-0.86^{* *}$ & $-0.94^{* *}$ \\
CDU dominance & n.i. & n.i. & n.i. \\
GDP per capita & n.i. & $-0.00(1),($ n.s. $)$ & $-.00(1)$, (n.s.) \\
Migration & n.i. & n.i. & n.i. \\
adj. $\mathbf{R}^{2}$ & 0.5350 & 0.5169 & 0.6322 \\
\hline
\end{tabular}

24 This is the coefficient for the model with robust standard errors (hc3), since it is significant opposed to the less restrictive model. 